\title{
The Kirtan of Resistance and a Divided Bengal: A Study of the Matuya Community
}

\author{
Sujay Thakur \\ Jawaharlal Nehru University, New Delhi
}

This research paper aims at examining ways in which Hari Chand Thakur (1811-1877), steered the low-caste Namasudras in the late nineteenth-century towards a distinctive social identity. It will also focus on how Hari Chand brought almost the whole Namasudra community under one Matua sect with the help of his simple namgans of Lord Hari - which, infused with social messages, bequeathed the caste subaltern a voice of dissent through devotional membership. But one hardly finds mention of Hari Chand's kirtan and its attendant social regenerative agenda in studies of this form of cultural performance. Through my intervention in this field, I shall discuss the politics behind underplaying the contribution of Hari Chand Thakur's cultural initiatives in popular and political discourse on social reformation in late nineteenth/ early twentieth century Bengal. To substantiate the argument this article takes the theoretical framework of John Rawl's A Theory of Justice. Since then many political philosophers and theorists have increasingly been concerned with the issue of ethnocultural diversity within the ambit of secular state(s). That whether justice can happen at all when state's decision is binding over that of an individual or sects. Some have argued that liberalism has neglected the importance of culture and ethnicity in politics of secularism. The difference-blind model of unitary citizenship that had been favoured by liberals was challenged by the emergence, both in theory and practice, of the recognition of minority sects' rights and of a model of differentiated or plural citizenship that the Left government of West Bengal tended to espouse. On the other hand the govt of Bangladesh went more into religion based citizenship than just a fair Republic. The fact that this community departed from Faridpur, and other places in Bangladesh is a testament of the intolerance even after their philanthropy for the lower-caste Hindus of that country. Slowly and steadily the matuya community had to shift to the safety of West Bengal in order to survive. Kent Greenawalt measures such establishment of religion as an adverse affect on the standing of citizens, giving a lesser standing to people who do not embrace the officially supported religion(s) and makes these individuals feel like "outsiders".

In the same spirit, Habermas suggests that religious reasons may be introduced in political advocacy in the "informal public sphere"-newspapers, political talk shows, street demonstrations, town meetings, etc.- - but that they should be translated into public reasons if they are to pass the institutional threshold of the formal public sphere including "parliaments, courts, ministries and

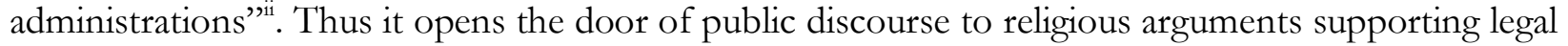
reforms, can be made by ordinary citizens within the informal public forum provided they are translated into secular public reasons when entering the formal public sphere of state institutions. For a country like Bangladesh which was formed on the principal of prevalence of a singular language amongst others, forming religious divide was a backlash for the Hindus who all of a sudden were the minorities just like the Muslims on the Indian counterpart. The problem, amongst many was a cultural cohesion that Bangladesh found diminishing soon. 
In this light substantial research has been done on Hari Chand Thakur and the Matua sect while discussing colonial caste-policies, that of the Indian National Congress, Hindu-Muslim disparity, or the urban ideologies of social reawakening in early $20^{\text {th }}$ century Bengal. Sekhar Bandopadhyaya has significantly contributed to the study of caste-based cultural communities articulating social resentment through his works titled Caste, Protest and Identity in Colonial India: the Namasudras of Bengal; Caste Culture and Hegemony: Social Domination in Colonial Bengal and Partition and the Ruptures in Dalit Identity Politics in Bengal. Research along developmental paradigms has also been done by Willem van Schendel and Abhijit Dasgupta in Development and Underdevelopment in Bengal: Castes, Communities and the State. Projit Bihari Mukharji has analysed the nineteenth century class-caste conflicts and consequent projects of communitarian identity-formation in his book Structuring Plurality: Locality, Caste, Class and Ethnicity in Nineteenth-Century Bengali Dispensary.

But none of these looks into how the tradition of kirtan becomes instrumental - by its perlocutionary potential - as an agent of communal consciousness and thereby leads to a solidarization of the Matua sect. My paper intends to focus on the performative politics of kirtan of Hari Chand Thakur - and how the democratization of 'devotion' through proximal collectivities within the ritual space of this bodily performance made way for a reorganization of the sect. I will try to show how his kirtan caused a 'will to social ascent' within this downtrodden caste.

My paper aims at depicting the ways in which Harichand Thakur, with the help of kirtan, steered the way for the Namasudras in the late $19^{\text {th }}$ century, to make them a formidable part of the society. My paper will also focus on how Harichand brought almost the whole Namasudra community under one Matua sect with the help of his simple namgans of Lord Hari mixed with social messages, which in later years helped them forming a solid platform wherefrom they could make their presence felt. I also intend to discuss the reasons behind the politics of keeping Harichand Thakur at bay, though his work not only helped the Namasudra community to have their rightful voice, but also helped in making an egalitarian society by making the downtrodden stand up on his feet and make their presence felt in the society.

Kirtan existed even before Sri Chaitanya popularised it in the $16^{\text {th }}$ century, and was generally practised widely and much more openly thereafter. It was one the rare places where all social distinctions were forgotten and the listeners used to shed (unknowingly or knowingly) all the social inhibitions.

Sri Chaitanya led the world in chanting the song of Radha and Krishna, but largely, these forms of art couldn't help much in upwardly mobilising the lower caste Hindus. Though Chaitanya never discriminated on the ground of caste, creed or colour, the society was such that any mobility in caste structure was next to impossible. Added to that, Chaitanya's kirtan never opposed the caste system as vehemently as Nanak or Kabir ${ }^{\text {iii }}$.

It was Sri Harichand Thakur of Odakandi of greater Faridpur district of Bangladesh, who took the first step to organize the chandals (later to be called as the Namasudra under Harichand Thakur's initiative leading to the British administrative order of implementing the same) under the banner of a singular Matua Community. His kirtans were simple lyrics with no ragas or gourachandrikas or any such art forms. The songs were aimed for the social growth of Namasudras and other social subalterns. Anybody from any caste and class was welcome to the congregation. Himself being from a Maithili Brahmin family, he married a lower caste woman to set example for what he believed in. The very identity of Harichand made the Namasudras all the more enthusiastic as here was a Brahmin with lower caste wife, talking about upliftment of the whole community and 
initiating reforms through simple namgaans. The accommodation of a Brahmin in Namasudra community gave a whole new impetus to raise the awaited voice against social injustice upon them.

To raise the voice, Harichand knew that he has to organise the scattered people of the caste, all over Bengal. Not all of the concerned community followed him, but a majority of the dominant Namasudra, from the educated middle class to the agriculture based lower class, joined the Matua sect. Kirtan played as a catalyst in bringing them under one common roof. Songs like, 'jar dal nei, tar bal nei', (one who doesn't have a group doesn't have any power) gave them the ideology by which they could protest. People from Faridpur, Dacca, Bakarganj, Khulna, Jessore, etc. joined the sect. Education began under the supervision of Guruchand Thakur - son of Harichand Thakur. It started in 1870 as a lower primary school for few years until the Christian missionary from Australia helped it out to become a higher secondary school.

For the Namasudra devotees of Matua sect, kirtan was also a source of collective strength. The namgaans emphasised the super power of the gurus, both Harichand and Guruchand, who could help their disciples to overcome all the crises of their lives. The namgaans are actually compositions which helped the Namasudras to assert their collective will and raise their voice against any injustice of the society. The songs were aimed at the generation of self - confidence in these politically powerless and ill - equipped people, to face the hazards and obstacles of life:

'dam dam maro danka, chinde phelo sab sanka ...

Bhabna aar koris ki, benche theke moris ki?

Jago, jago, jago bir, soja kore rakho sir,

Jak jan, benche thak man ...'

( ... What are you thinking? Are you going to behave as if you are dead? Hold your heads high, do not give up self - respect, even if you have to sacrifice your life.)

Two main communities dominating the scheduled caste politics in West Bengal were the Namasudras followed by the rajbansis. Namasudra formed the third largest Hindu caste but remained 'untouchable'.

Though in Bengal the untouchability never stooped to levels as low as in Maharashtra, still the politics and its authority remained largely in the hands of the upper castes. In Bengal, caste rigidities were never strong enough to keep the untouchable population in a state of perpetual servitude. In this context, the types of discrimination faced by depressed or scheduled caste leaders like Jogendranath Mandal were not the same as those experienced by Ambedkar in Maharastra. In Bengal the list of scheduled castes included not only the 'untouchables' also known as, as Bhavadeba Bhatta would call them Atanjya jati ( the Doms, chandalas, shabaras, kapalikas and others) but also others who ritually ranked a step above them. The colonial bureaucracy enlisted communities under the Scheduled Caste, grouping them not much in accordance to their ritual status, but more in terms of their economic status. Therefore, it has been argued that since the intensity of untouchability was relatively weak in Bengal, compared to some other regions of India, movements such as those demanding right of entry to temples could never become a major plank in the movement for the removal of untouchability. The problems of untouchability and those of social ostracism were reflected in the antagonisms that prevailed between the indigent Chhotoloks (low borns) and the rich Bhadraloks (men enjoying a higher status by virtue of their ritual ranking, education and other virtues) in the society. At times movements among the Bengali untouchables assumed class connotations. 
In 1880s, when the Bengal literati was chanting names of rich cultural values, Harichand emphasized on the simplistic way to teach people, which often tended to violate the given rules of the upper caste Hindus. The Matuas believed in equality of living beings. Emphasis on every object was so stressed, that even food leftover by dogs was considered holy in nature:

Hari dhyan Hari jnan Hari nam

Premete matoyara Matua nam

Jibe daya name ruchi manusete

Iha chbada ar yata sab kriya

Kukurer prasad pele khai

Veda-bidhi shauchachar nabi mani tai.

(Hari is the only name in the cosmic world, we all are absorbed in the Matuya name, compassion for the living being is what we care for/ we share our food with the dogs/ so we don't accept the division amongst people)

Mobilisation among the different sub castes in lowest categories was one of the main objectives of Harichand Thakur and his son Guruchand Thakur. The Matuas sang the compositions which mainly suggested how to lead a good life. It included the ways to lead a responsible family life too. The art of moulding the high cultured kirtan of Chaitanya was perfectly mastered by Hari Thakur. But his being a Brahmin who devoted his life for the cause of the lowest caste, might be the potential cause of his being marginalised in the world of social reformation through kirtan.

Kirtan was sung collectively, it gave the sect a congregational character and helped its predominantly Namasudra devotees to construct and reinforce their collective identity through shared experience of devotion. The kirtan of the Matua community hailed Hari Thakur as the avatar of Krishna and Chaitanya because of his sarva dharma samanaya (unity amongst all religion). While we go overboard about the Ramakrishna-Vivekananda movements and that of Chaintanya Deb, we would hardly be familiar with the Matua religious movement that was contemporary and very much influential in East Bengal, particularly the region dominated by the Namasudras ( primarily "Southcentral", comprising the districts of Jessore, Faridpur and Bakerganj/Barisal).

The politics of Hari Thakur to organise the unorganised sudras (later to be known as the Scheduled caste under the British order), who form the majority, spans beyond his work period (1830s to 1870 s). It is he who initiated the process later to be taken forward by Jogendranath Mandal in undivided Bengal. It is interesting to note that though the Matua community tried to cut out itself from the caste ridden Hindus, they by and large followed all the Hindu rituals. Even their lord Harichand Thakur advised them to stick to the 'openness' of Hinduism by understanding it to the fullest. This gives ample scope to raise questions about the basic politics behind the 'Hari sabhas' organised by him to make the people aware of their potentials in the real world. More than blind rituals, the Matua community was made aware of education and gender equality. This led to the emergence of several elites and educated people among the community, who in later period helped the whole community to step forward at par with other castes and creeds.

The movements under the initiative of these Hari sabhas need to be analysed in two different ways. In the first place, such sabhas can sometimes be considered as manifestations of protest against the dominant system of social organisation that sanctioned disabilities and inflicted deprivation on certain subordinate groups. On the other hand such movements could be read as expressions of 
ambitions or aspirations that sought accommodation and positional re-adjustments within the existing system of distribution of power and prestige. It would be worthwhile to argue that within such 'untouchable' social groups, different levels of social consciousness and different forms of political action emerged, which inevitably were incorporated within a single movement. In Bengal, due to their socio-economic backwardness, some of the lower or 'untouchable' castes developed worldviews that were fundamentally different from that of the nationalists and this led to their alienation from mainstream politics. However within the same social movement of such ritually 'inferior' castes, there could be a convergence of different tendencies - some protestant and some accommodating. In fact, as a result of such tendencies, lower caste social protest in spite of the immense possibilities of initiating some fundamental changes in society or polity, fell far short of the cherished goals.

To conclude, I must emphasize on the anti - nationalistic approach that the Matuyas took during the independence and the partition period of India, which led to the severe setback of the community on the political platform. As a result, even in the 1990s and early 2000, the matuya community wasn't reckoned with as much importance as the Trinamool government has. Today the total population of the sect is more than a crore and the government, for reasons right or otherwise, has put its focus on them. The fact of why this community tried to focus internally rather than on the whole lower caste/class barrier of undivided Bengal is still to be debated, and that would take more than one article.

Also, it should be duly noted that it was Gandhi who first realized the dichotomy between political self-rule and social empowerment (which led the namasudras to take the anti- nationalistic stance), and the efforts that he took to remedy the imbalance, made him India's first grassroots political leader. The Namasudras however took a different track to Gandhi's struggle for Harijan rights - this came from the peculiar advantages that Bengal enjoyed both in terms of the relative laxity of the untouchability system and the close association with progressive British values and education system mediated via the Bengal Renaissance. While Gandhi organized marches for Harijans to be allowed into temples, and tried to rally them almost spiritually and somewhat condescendingly into a social force very much akin to the Hindu tradition, the Namasudra leaders made much more concrete and practical demands - that of greater representation in the political process, better access to education and jobs, and empowerment through the colonial western modes of power, that Gandhi was naturally wary of. Whatever the cause might be, the Namasudras had gone mobile by and far above the expectation at a time ripe enough to take what had been denied for ages to them. From literacy level of 3\% it rose to 30\% within a year which was at par with the then national literacy level. The main propelling factor being Harichand Thakur's reformation measures somewhat got curtailed mostly due to the partition where the then East Pakistan had all the active areas of these people. There these people were clubbed along with the Hindus within no time and made the minorities. Added to that was Jogendra Nath Mandal's candidature for ministry at the newly formed East Pakistan where he thought to have gained more advantages for the Scheduled castes until 1950s when he had to witness mass torture of the lower caste Hindus and their migration to India thereafter. On the current date the Matuya sect has considerable presence in and around Nadia, 24 Parganas and some parts of North Bengal. Acknowledgment of the contribution of this sect for the social mobility is almost at the brink of oblivion as the class construct has gained largely at the cost of caste consciousness. The predominant glorification of Harichand Thakur by the community without sufficiently addressing the cause he upheld clearly had no major fruitful outcome especially after the partition of Bengal. Above all, the state govt.'s decade - long reluctance to bring forward and showcase this gradually diminishing form of naamgan adds 
to the misery of its being. Songs now merely provide entertainment value to the uneducated masses mainly in villages and are organized privately. Until and unless there are major steps to atleast showcase this form of art, the possibility its extinction in future will be near impossible to avert.

\section{Notes}

i Greenawalt, Kent (2008), Religion and the Constitution. Volume 2: Establishment and Faimess, Princeton and Oxford: Princeton University Press.

ii Habermas, Jürgen (2006), "Religion in the Public Sphere", European Journal of Philosophy, 14/1, 1-25.

iii Community Formation and Communal Conflict: Namasudra-Muslim Riot in Jessore-Khulna by Sekhar Bandyopadhyay, Economic and Political Weekly, Vol. 25, No. 46 (Nov. 17, 1990)

\section{References:}

Alexandrowicz, C.H. The Secular State in India and the United States. Journal of the Indian Law Institute, 1960. Print.

Bader Veit (2003), “Taking Religious Pluralism Seriously. Arguing for an Institutional Turn. Introduction”, Ethical Theory and Moral Practice, Vol. 6, No. 1, Religious Pluralism, Politics, and the State (Mar., 2003), pp. 3-22, Published by: Springer Stable, Accessed: 18/03/2011 07:33, URL: http://www.jstor.org/stable/27504260

Bandyopadhyay, Sekhar. Community Formation and Communal Conflict: Namasudra-Muslim Riot in Jessore-Khulna. Economic and Political Weekly. Vol. 25, No. 46 (Nov. 17, 1990), pp. 2563-65, 2567-68. http://www.jstor.org/stable/4396995. Web. 06/07/2010

-'Partition and the Ruptures in Dalit Identity Politics in Bengal', Asian Studies Review, 33: 4. 2009. 455-67. Print

Kent, S., 1993, New Religious Movements, The Sociology of Religion: A Canadian Focus, Toronto, Butterworths, pp. 83-106. Print.

Mukharji, Projit Bihari. Structuring Plurality: Locality, Caste, Class and Ethnicity in Nineteenth-Century Bengali Dispensari. Health and History. Australian and New Zealand Society of the History of Medicine Vol. 9, No. 1 (2007), pp. 80-105. Print.

Nandy, Ashis. The Politics of Secularism and the Recovery of Religious Tolerance. Alternatives, Vol.13, No.2, April 1988. Print.

Sanyal, Hitesranjan. Continuities of Social Mobility in Traditional and Modern Society in India: Two Case Studies of Caste Mobility in Bengal. Journal of Asian Studies, Vol. 30, No. 2 (Feb., 1971), pp. 315-339. http://www.jstor.org/stable/2942917. 06/07/2010

Schendel, William van, Abhijit Dasgupta. Development and Underdevelopment in Bengal: Castes, Communities and the State. Economic and Political Weekly, Vol. 27, No. 14 (Apr. 4, 1992), p. 692.Print.

Waterhouse, Eric S. Secularism, in Hastings, James (ed.), Encyclopaedia of Religion and Ethics, Vol.1l, T\&T Clark, Edinburg, 1967. Print.

Venkataramani, Sh. Why the World is becoming More and More Unsecular. The Pioneer, March 21, 1994. Print.

Sujay Thakur is a PhD Research Scholar at Jawaharlal Nehru University, New Delhi. 